[inicjacje schulzowskie]

\title{
Marta Cwalina: Świat ludzki w twórczości Brunona Schulza
}

„Świat ludzki jest dla p. Schulza najdalszym ze światów. Przypuszczam, że gdyby można było odcyfrować wrażenie antylopy spotykającej człowieka, to byłoby coś podobnego do wizerunków ludzkich p. Schulza"1. To właśnie oderwanie od człowieka, posunięte wręcz do dehumanizacji, naruszenie zasady principium individuationis, niedostateczne wyeksponowanie wewnętrznej struktury bohaterów i obojętność na problemy społeczne były najczęstszymi zarzutami wysuwanymi przez pierwszych krytyków wobec twórczości Brunona Schulza. I choć wiele $\mathrm{z}$ tych cech można odnaleźć na powierzchni jego tekstów, nie sposób sprowadzić do nich wielopłaszczyznowej wizji rzeczywistości, jaka zarysowuje się w dziele pisarza. A był on pisarzem w szczególny sposób w tejże rzeczywistości zakorzenionym. Zgodnie z jego filozofią słowa (która swój najpełniejszy wyraz znalazła w Mityzacji rzeczywistości, będącej czymś na kształt manifestu programowego), zasadą literatury, a ściśle rzecz biorąc, „poetyckości”, jest słowne docieranie do ontologii rzeczywistości pozasłownej² . Daje to podstawy do szukania śladów tego współczesnego pisarzowi świata na kartach jego opowiadań. Był to świat przełomu XIX i XX wieku, epoka ze wszech miar rewolucyjna. Złożyły się na nią doniosłe odkrycia w dziedzinie nauk ścisłych, wykwit nowych ideologii politycznych, a także degradacja dotychczasowego modelu życia społecznego. Teoria względności i psychoanaliza, rewolucja przemysłowa i biologiczne eksperymenty Carrela, emancypacja kobiet i kultura masowa. Zmiany dotyczyły

1 A. Grzymała-Siedlecki, Etiudy płanetnicze, „Kurier Warszawski” 1934, nr 11 (wyd. wieczorne), s. 4.

2 Por. W. Bolecki, Wenus z Drohobycza, Gdańsk 2017, s. 103. 
każdego aspektu ludzkiego życia. Prowokowały do stawiania pytań o miejsce człowieka w nowym świecie, a także o przyszłość samego świata, na które nie znajdywano satysfakcjonujących odpowiedzi. Niepokoje te skumulowały się w modernistycznych nurtach dekadenckich, których reperkusje wciąż nie dawały o sobie zapomnieć w okresie dwudziestolecia międzywojennego.

Wszystko to nie ominęło, rzecz jasna, prowincjonalnego, wielokulturowego Drohobycza, a wraz z nim mitycznego miasta z opowiadań Schulza. W 1896 roku w bezpośrednim sąsiedztwie Drohobycza rozpoczęto eksploatację ropy naftowej na skalę przemysłową. Naftowy boom sprowadził do miasta nie tylko „kreatury bez charakteru, bez gęstości”, próbujące zbić kapitał w pobliskim Borysławsko-Drohobyckim Zagłębiu Naftowym, lecz także pewne nowe normy zachowań - „trzeźwą użytkowość”, „zniwelowanie granic i hierarchij”. Jednak i tutaj pojawia się dla interpretatora pułapka. Nadmierne skoncentrowanie na historii miasta (nazwa "Drohobycz” nie pojawia się w opowiadaniach ani razu ${ }^{3}$ ) i biografii samego pisarza odbiera walory uniwersalne jego wielkim metaforom. Odbiera im „sens uniwersalny”, stanowiący, zdaniem Schulza, podstawę nie tylko literatury, lecz także samej rzeczywistości. „Wszelkie próby dosłownego potraktowania świata Schulza kończyły się niezamierzoną karykaturą"4 - twierdzi słusznie Włodzimierz Bolecki. I tak pojawiały się opinie, według których Schulzowski oniryzm jest wyrazem deformacji psychicznych, jakim ulegają ludzie $\mathrm{w}$ warunkach małomiasteczkowej kultury ${ }^{5}$, a dramat osobisty i rodzinny narratora stanowi obraz dramatu galicyjskich Żydów, wyraża bunt przeciwko położeniu mas żydowskich w Polsce i solidarność z nimí.

Jak więc szukać w dziele Schulza śladów diagnozy współczesnego mu społeczeństwa, by nie popaść w skrajności? Jak wyważyć te dwie tendencje - z jednej strony chęć dokładnego odszyfrowania twórczości pisarza poprzez przełożenie opisywanej rzeczywistości na realia Drohobycza, z drugiej zaś podążanie za oniryczną wizją, zanurzenie w fantastycznym świecie i niechęć do wychodzenia poza jego granice? Jaka jest recepta? Przypuszczam, że Schulz poradziłby nam zapytać markownika. Markownik jest autentykiem. Czym zaś jest autentyk? W odróżnieniu od „skażonego apokryfu” - Biblii - jest księgą właściwą, mitologią, stanowiącą źródło wszelkich ludzkich historii. Zgodnie z Schulzowską wizją poezji powinna być ona dążeniem do odkrywania tekstu autentyku. Owego „pierwotnego słowa”, „majaczenia krążącego wokół sensu świata”. Można więc przypuszczać, że zrekonstruowanie markownika było nadrzędnym celem, do którego Schulz dążył w swym pisarstwie. „Markownik jest księgą uniwersalną, 
jest kompendium wszelkiej wiedzy o ludzkim. Naturalnie w aluzjach, potrąceniach, w niedomówieniach. Trzeba pewnej domyślności, pewnej odwagi serca, pewnego polotu, ażeby znaleźć wątek, ten ślad ognisty, tę błyskawicę przebiegającą stronice księgi. Jednej rzeczy trzeba się wystrzegać w tych sprawach: ciasnej małostkowości, pedanterii, tępej dosłowności. Wszystkie rzeczy są powiązane, wszystkie nici uchodzą do jednego kłębka. Czy zauważyliście, że między wierszami pewnych książek przelatują tłumnie jaskółki, całe wersety drgających, spiczastych jaskółek? Należy czytać z lotu tych ptaków..."7. I to będzie właśnie przedmiotem niniejszych rozważań - czytanie z lotu jaskółek.

Obecność Schulza wśród członków założycieli Zespołu Literackiego „Przedmieście” budzi w gronie badaczy wiele kontrowersji. Zwykle traktowana jest jednak jako nic nieznaczący epizod, nieprzemyślany, niezrozumiały wybór ledwie debiutującego pisarza (książka zbiorowa zespołu, zawierająca program i pierwsze prace, ukazała się w 1934 roku, Schulz debiutował w roku 1933). Dla interpretacji tego faktu znamienne jest, że Schulz nie opublikował w zbiorowym tomie żadnego tekstu oraz że jedną z osób zaangażowanych w prace Zespołu była Zofia Nałkowska - protektorka pisarza, która doprowadziła do wydania Sklepów cynamonowych. Być może to za jej namową Schulz podjął decyzję o dołączeniu do „Przedmieścia”, a może była ona jedynie wynikiem prywatnej wrażliwości pisarza. Są to czyste spekulacje. Jednak w ramach powziętej uprzednio zasady „czytania z lotu jaskółek” postaram się, mimo wszystko, przyjrzeć przedmowie programowej Zespołu i poszukać w niej elementów, które mogły się wydać Schulzowi bliskie.

Zacznijmy od nazwy tej grupy literackiej. „Przedmieście, jako nazwa Zespołu, posiada znaczenie symboliczne. Przywołuje na myśl nie tylko dzielnice przedmiejskie, lecz także to wszystko, co żyje w Polsce na przedmieściach kultury, a więc: mniejszości narodowe, proletariat wiejski i miejski pracujący jeszcze i już bezrobotny, wszelką nędzę społeczną, wszelką krzywdę i ucisk, wszelkie masowe cierpienie «za niepopełnienie win» $[\ldots]$ ".8. Opozycja przedmieście-centrum (czy też, jak nazywa ją Jerzy Jarzębski, prowincja-centrum ${ }^{9}$ ) jest ważną kategorią, wokół której konstytuują się znaczenia Schulzowskiej prozy. To właśnie tę opozycję wykorzystuje pisarz, chcąc skontrastować to, co nowe, nieznane, $z$ tym, co tradycyjne, zastane. O obecności tych wątków w Schulzowskiej przestrzeni miejskiej, a także o symbolice miejskiego labiryntu obszernie pisał Artur Nowaczewski w książce Szlifibruki i flâneurzy ${ }^{\mathbf{1 0}}$.

7 B. Schulz, Wiosna, w: idem, Opowiadania. Wybór esejów i listów, oprac. J. Jarzębski, Wrocław 1989, s. 168.

8 H. Krahelska, Przedmowa, w: Przedmieście, Warszawa 1934, s. V.

9 Por. J. Jarzębski, op. cit.

10 Por. A. Nowaczewski, Walka konkretu z symbolem. "Odzyskiwanie symboliczne” ulic po Jałcie, w: idem, Szlifibruki i flâneurzy. Figura ulicy w literaturze polskiej po 1918 roku, Gdańsk 2011, s. 197-203. 
W centrum miasta - mikrokosmosu narratora - znajduje się rynek. Rynek jest także centralnym miejscem labiryntu, w którym młodociany bohater-narrator zaraz się gubi, gdy tylko opuści bezpieczny, znany kwartał ulic. Według ukonstytuowanej w kulturze symboliki labiryntu jego centrum jest miejscem świętym, symboliczną Jerozolimą, do której podążali, śladami mozaikowych posadzek, odwiedzający średniowieczne katedry wierni ${ }^{11}$. To tutaj przechowywane są wartości ${ }^{12}$. Rynek jest więc ostoją tradycji, pełnego solennej ceremonialności handlu, patriarchatu, świata ojca. To właśnie przez rynek „przechodzi na wskroś całe wielkie lato". Wszystko, co naturalne, wpisane w odwieczny cykl, odbywa się na rynkowym bruku. Przechodnie odwiedzający centrum nie ulegają żadnej namiętności, żadnej ludzkiej sprawie, która wyrwać by ich mogła z podyktowanego przyrodą rytmu. Wszyscy z „zalepionymi miodem” oczami i „bakchicznym grymasem" na ustach zdają się, podobnie jak lato, majestatycznie przepływać przez rynek. W tej atmosferze wyjątkowości nietrudno o miłosiernego samarytanina, którym w tych warunkach może się stać każdy z nich. Inaczej jest ze zlokalizowaną na przedmieściach ulicą Krokodyli. Jej wątpliwy moralnie charakter podkreśla peryferyjne usytuowanie na mapie miasta wyraźnie zakreślona, odróżnia się wyraźnie od reszty barokowego prospektu. „Duch czasu, mechanizm ekonomiki nie oszczędził i naszego miasta i zapuścił chciwie korzenie na skrawku peryferii, gdzie rozwinął się w pasożytniczą dzielnicę"13.

Oprócz dzielnic przedmiejskich ważną kategorią dla programu Zespołu jest pojęcie „przedmieść kultury”. I choć u Schulza nie zamieszkują ich jasno określeni przedstawiciele konkretnych grup społecznych, tylko raczej ów niesprecyzowany "gmin” - „szumowiny”, „lichota moralna”, „ta tandetna odmiana człowieka” dość wyraźnie zarysowuje się wspólna im cecha, jaką jest obcość. Zostali przeciwstawieni rdzennym mieszkańcom miasta, jako jego nowi obywatele potrafią jedynie imitować prawdziwie miejski styl życia. Zdaje się więc, że mogą oni wywodzić się z warstw niższych niż tradycyjne mieszczaństwo, którym awansować pozwoliła dopiero „nowoczesność. Są więc tej nowoczesności prawdziwymi ambasadorami. Jeszcze jeden trop, już pozaliteracki, wskazuje na zainteresowanie Schulza „wszelką nędzą społeczną”, na jego szczególną wrażliwość na masowe cierpienie, ale również na jego przeczucia dotyczące kierunku zmian społecznych. Według jednej z relacji: „Często ze swoimi uczniami chodził na Łan, to była stara dzielnica żydowska, późniejsze getto. I malował te drewniane, na wpół rozwalone domy, tych smutnych, wyczerpanych ludzi. Często tam chodził. Kiedyś jeden z uczniów zapytał go: «Panie profesorze, dlaczego pan tak lubi malować tych

11 Por. Labirynt, w: J. E. Cirlot, Słownik symboli, przeł. I. Kania, Kraków 2000, s. 219-220.

12 A. Nowaczewski, op. cit., s. 199.

13 B. Schulz, Ulica Krokodyli, w: idem, Opowiadania. Wybór esejów i listów, s. 71. 
biednych ludzi i te nieszczęsne biedne domki?». A on odpowiedział: «Muszę to uczynić, gdyż wcześniej lub później to zniknie»"14.

Lecz „przedmieście” oznacza coś jeszcze. „Czyż nie wyraża tego samego, co słowo awangarda?” - pyta retorycznie Krahelska w przedmowie do zbioru tekstów Zespołu ${ }^{15}$. Obszerne badania na temat skomplikowanych związków Schulza $\mathrm{z}$ awangardą przeprowadził Włodzimierz Bolecki ${ }^{16}$, warto jednak $\mathrm{w}$ tym miejscu wypunktować kilka cech awangardowych, które można znaleźć w twórczości drohobyckiego pisarza. Pewien problem stanowi wieloznaczność samego terminu. Do krytyki artystycznej nazwa ta przeszła za pośrednictwem ideologii socjalizmu utopijnego - artysta awangardowy w rozumieniu socjalistów to artysta zaangażowany w problemy społeczne, tworzący sztukę utylitarną i społecznie użyteczną ${ }^{17}$. Charakter przedmowy do pierwszego wydania „Przedmieścia” może sugerować, że w tym znaczeniu rozumiała awangardę Krahelska. Jest to wprawdzie jedno z pierwotnych znaczeń tego terminu, jednak zdaniem Grzegorza Gazdy w Polsce pojęcie to niemal bez wyjątku kojarzone było z programem i poetyką Peipera ${ }^{18}$. Szczególnie w latach trzydziestych, gdy świeża była pamięć o postulatach Awangardy Krakowskiej, działającej w latach 19221927. A więc również o takich założeniach, jak dowartościowanie metafory jako centralnej kategorii języka poetyckiego (Schulz przejął tę koncepcję, ale przypisał metaforze zupełnie nowe funkcje ${ }^{\mathbf{1 9}}$ ), skoncentrowanie raczej na zdaniu niż na słowie (u Schulza tendencja ta łączy się z koncepcją le mot juste - słowa precyzyjnego, właściwego ${ }^{20}$ ), pasja eksperymentu czy szerokie zastosowanie w twórczości literackiej słownictwa z nowych dziedzin wiedzy, wyrazów technicznych, specjalistycznych.

W przedmowie wyszczególnione zostały także cele i zadania Zespołu. Halina Krahelska cytuje współzałożyciela „Przedmieścia”, Jerzego Kornackiego: „Odchodzimy od biurka, zakładamy warsztat pracy na ulicy - kontemplację artystyczną w czterech ścianach pokoju zamieniamy na podróż pełną rzeczywistych zdarzeń. Nudzi nas wiekuista fikcja - reflektor naszej uwagi, naszej obserwacji, naszego talentu kierujemy na dziko dziewiczy, bujny i rozmaity świat "przedmieścia»"21. W pierwszym momencie wydaje się, że nie ma nic bardziej

14 W. Budzyński, Schulz pod kluczem, Warszawa 2013, s. 68.

15 H. Krahelska, op. cit., s. V.

16 Por. W. Bolecki, Język poetycki i proza: twórczość Brunona Schulza, w: idem, Wenus z Drohobycza, S. $86-160$.

17 Por. G. Gazda, Awangarda, w: Słownik literatury polskiej XX w., pod red. A. Brodzkiej, M. Puchalskiej, M. Semczuk, A. Sobolewskiej, E. Szary-Matywieckiej, Wrocław 1993, s. 63.

18 Ibidem.

19 Por. W. Bolecki, Awangarda, awangardowość, w: Słownik schulzowski, oprac. W. Bolecki, J. Jarzębski, S. Rosiek, Gdańsk 2006, s. 35.

20 Idem, Wenus z Drohobycza, s. 95-96.

21 H. Krahelska, op. cit., s. VI. 
sprzecznego z duchem pisarstwa Schulza niż idea odwrotu od fikcji i skoncentrowania się na rzeczywistych zdarzeniach. By więc zrozumieć sens tej antynomii, musimy uciec się do pewnej operacji na samym terminie "fikcja”, a mianowicie spróbować dopuścić możliwość, że coś może być jednocześnie fikcyjne i prawdziwe. Sięgnijmy znowu do Mityzacji rzeczywistości. Już sam tytuł tego najważniejszego z pism krytycznych Schulza jest jak gdyby streszczeniem przyjętej przez niego koncepcji sztuki. Jej podstawą jest rzeczywistość, to ona jest kośćcem, na którym artysta nadbudowuje mitologię. Lecz nie po to, by rzeczywiste zdarzenia przekształcić $\mathrm{w}$ fantastyczne wytwory wyobraźni artystycznej. Świat realny nie jest w tym zamierzeniu jedynie inspiracją dla świata fikcji, ale służy temu, by wydobyć daną historię z jej macierzystego kontekstu - wpisać ją w sens uniwersalny. Umitycznić znaczy tylko tyle, co usensowić. Na tym właśnie polega stosowany przez Schulza zabieg odrealniania zdarzeń - są na tyle niepodobne do swoich pierwowzorów, że zyskują wartość obiektywną. Fikcja służy mu do odkrywania przed czytelnikiem prawdziwej istoty wydarzeń - jedynego ich niezmiennego składnika, który zawsze będzie ten sam: ponad ich jednostkowymi rysami. Sam pisarz w jednym ze swych listów do władz szkolnych podkreślał: „Dzisiejsza chwila historyczna nacechowana zagęszczeniem zagadnień, pulsująca od problematyki nie pozwala ani na chwilę na duchową izolację. Kto utraci kontakt $\mathrm{z}$ duchowym życiem epoki, przestaje być aktualnym w swojej twórczości, nie wchodzi w rachubę jako artysta"22. To właśnie głębokie zakorzenienie w rzeczywistości, dokładna jej obserwacja jako niezbędny element pracy artystycznej, jako legitymacja twórczości pisarskiej, może najbardziej zbliża Schulza do Zespołu i jego metodologicznych postulatów.

Kolejną cechą, która zdaje się wspólna Schulzowi i „Przedmieściu”, jest przeczucie zbliżającego się kresu dotychczasowej kultury i struktury społecznej. W cytowanej przez Krahelską wypowiedzi czytamy dalej: „Zapuszczamy się w naszą podróż po przedmieściach w wieczną i chmurną niepogodę, kryjącą w sobie zapowiedź czasu przemian. Czyżby właśnie te z głębi rosnące pomruki i fale przedmieścia sprawiły, że oto my, na suchym brzegu jeszcze żyjący i ślepi dotychczas i głusi, dostrzegliśmy, usłyszeliśmy i zrozumieliśmy nie tylko żywioł ów otaczający nas, ale i naszą doń przynależność? Oddalamy się od nadbrzeżnego śródmieścia i stajemy się dlań «widowiskiem literackim», czyżby jedynie dlatego, że mamy na dnie przeczucia pewność, iż dłużej naszego «widowiska», niż widzów gapiących się w śródmieściu?"23. Ta atmosfera schyłku była zresztą charakterystyczna dla epoki Schulza, zakorzenionego w znacznym stopniu w modernizmie. Jest to kolejny punkt zbieżny pisarza i jego grupy literackiej.

22 B. Schulz, Dzieła zebrane, t. 5: Księga listów, zebrał i oprac. J. Ficowski, uzupełnił S. Danecki, Gdańsk 2016, s. 242.

23 H. Krahelska, op. cit., s. VI. 
Bruno Schulz był jednym z sześciu pisarzy należących do „Przedmieścia”. Było to grono wąskie, starannie dbające o dobór swych członków. W przedmowie zostali oni ściśle zdefiniowani: „do Zespołu należeć mogą tylko ludzie, poczuwający się psychicznie do czynnego zaangażowania po stronie człowieka pracy w jego wiekowej walce o prawo do życia, o zmianę ustroju gospodarczego i społecznego" ${ }^{24}$. Ponadto była to jedyna grupa literacka, do jakiej należał. Wskazując wyżej na pewne podobieństwa między programem Zespołu a realizacjami twórczymi Schulza, chciałam jedynie zasygnalizować możliwe zbieżności między nurtem prozy społecznie zaangażowanej a przepełnionymi metafizyką opowiadaniami pisarza. Była to próba rozważenia, zwykle wykluczanej, hipotezy, że z pełną świadomością podpisał się on pod założeniami tej grupy literackiej, że w przedmowie programowej możemy doszukiwać się konstytutywnych zasad jego pisarstwa z podobną pewnością, z jaką szukamy ich w Mityzacji rzeczywistości. Przynależność Schulza do „Przedmieścia” jest jednak nadal tylko tropem, sygnałem pozwalającym $\mathrm{z}$ większą dozą pewności poszukiwać $\mathrm{w}$ jego tekstach interesujących nas tutaj wątków społecznych.

Zostawiając już na boku deklaracje pisarza i jego prywatne wybory, przyjrzyjmy się nieco bliżej samym opowiadaniom. Jednym z najważniejszych w tym kontekście jest trzyczęściowy Traktat o manekinach. Stanowi on „program wtórej demiurgii”, jest zapisem tyrady ojca - starego Jakuba, który w obecności szwaczek wykłada swą heretycką filozofię. Wydaje się, że wiele rewolucyjnych sądów zostało tu wypowiedzianych niejako na próbę, cały monolog ojca jest bowiem w dużej mierze obliczony na efekt oratorski. Sytuacja, w jakiej wybrzmiewa przemowa, jest groteskowa i dwuznaczna. Nie pozwala to na traktowanie jej z całą dosłownością, zaciera się granica pomiędzy poważnym i niepoważnym. A wywód Jakuba obfituje w rewolucyjne pomysły balansujące na granicy inżynierii społecznej, także we wszelkiego rodzaju szarlatanerie i dyletantyzmy. Jego głównym postulatem jest wolność twórcza. „Wielki herezjarcha” odmawia Demiurgowi wyłącznego prawa tworzenia. Twierdzi, że jest ono domeną wszystkich duchów - nie wyłączając człowieka. Ale również człowiek (jak dowiemy się później - przede wszystkim człowiek) ma stać się obiektem eksperymentów, ową podatną materią. „Nie ma żadnego zła w redukcji życia do form innych i nowych. Zabójstwo nie jest grzechem. Jest ono nieraz koniecznym gwałtem wobec opornych i skostniałych form bytu, które przestały być zajmujące" 25 - przekonuje ojciec. Wieszczy tym samym koniec dotychczasowego modelu społecznego. Formy, które przybierali ludzie, normy zachowań i wzorce osobowe, które naśladowali, przestały być interesujące. Trwały ład społeczny, niezmienne

24 Ibidem, s. VIII.

25 B. Schulz, Traktat o manekinach albo Wtóra Księga Rodzaju, w: idem, Opowiadania. Wybór esejów i listów, s. 33. 
warunki rozwoju człowieka doprowadziły do skostnienia dawnych form. Jakub nie wierzy już w ich łagodną ewolucję, jedyną drogę widząc w ich unicestwieniu. Nadchodzi „druga generacja stworzeń”, która stanąć ma „w opozycji do panującej epoki”. Czym mają charakteryzować się nowe stworzenia? Przede wszystkim będą one zredukowane do roli, jaką wyznaczy im uprzednio nowy Demiurg. Tylko do jej wykonania zostaną powołane do życia, nie będą miały wszakże możliwości wyjścia poza nią. Zostaną ograniczone także fizycznie (do jednej połowy twarzy, jednej nogi czy ręki), co nie pozwoli im wejść w rolę inną niż narzucona. Ich konstrukcja uniemożliwi im wszelkie próby buntu. Są to bowiem ludzie stworzeni na obraz i podobieństwo manekina. Podobnie ludzi nowej epoki musiał wyobrażać sobie Oswald Spengler, który w Zmierzchu Zachodu charakteryzuje ich w następujący sposób: „martwe ciała, amorficzne i wyzbyte duszy rzesze ludzkie, zużyte tworzywo wielkiej historii - należy ujmować jako typowy symbol fazy końcowej"26. Taka wizja nowego człowieka przeraża. Przerażają także zakusy tego, który fantazjuje o możliwości stwarzania bezwolnych jednostek w celu zaspokojenia swych ambicji twórczych. Biologiczna strona tego eksperymentu przywodzi na myśl nasilające się od lat dziewięćdziesiątych XIX wieku próby realizacji postulatów eugeniki. Natomiast od strony psychologicznej programowe redukowanie życiorysów bohaterów do jednej roli, a tym samym redukowanie człowieka do funkcji narzędzia, wypełniającego swym życiem dokładnie przygotowany przez kogoś innego plan, przypomina mechanizmy propagandy reżimów totalitarnych. Lecz oprócz zachwytu nad nieskrępowanymi możliwościami twórczymi (i możliwością totalnej władzy nad stworzeniem) pojawia się w oracji ojca także pewne ostrzeżenie. Druga część Traktatu o manekinach pełna jest retorycznych pytań Jakuba: „Kto ośmiela się myśleć, że można igrać z materią, że kształtować ją można dla żartu, że żart nie wrasta w nią, nie wżera się natychmiast jak los, jak przeznaczenie? Czy przeczuwacie ból, cierpienie głuche, niewyzwolone, zakute w materię cierpienie tej pałuby, która nie wie, czemu nią jest, czemu musi trwać w tej gwałtem narzuconej formie, będącej parodią?"27. Ojciec zwraca tu uwagę na problem formy, która u Schulza bliska jest pojęciu Formy Gombrowicza. O pokrewieństwie tym zaświadczył zresztą sam autor Ferdydurke, pisząc o Schulzu i o sobie: „Pochłonięci byliśmy eksperymentowaniem z pewnym materiałem wybuchowym, który nazywa się Forma. Ale nie była to forma w znaczeniu zwykłym - tu chodziło o «stwarzanie formy», jej «produkowanie» i o «stwarzanie się poprzez stwarzanie formy»"28. Otóż to właśnie forma w znacznej mierze konstruuje istotę, która ją przybiera. Człowiek rzęcki, Warszawa 2014, s. 48.

27 B. Schulz, Traktat o manekinach. Ciag dalszy, w: idem, Opowiadania. Wybór esejów i listów, s. 38.

28 J. Jarzębski, Pojęcie „Formy" u Gombrowicza, "Pamiętnik Literacki” 1971, nr 4, s. 69-96. 
(lub też „manekin”) internalizuje formę narzuconą przez owego roszczącego sobie prawo do formowania Demiurga. „Płaczcie, moje panie, nad losem własnym, widząc nędzę materii więzionej, gnębionej materii, która nie wie, kim jest i po co jest, dokąd prowadzi ten gest, który jej raz na zawsze nadano" 29 - wzywa Jakub. Warto zwrócić uwagę na sformułowanie „nad losem własnym”, które to (powtórzone zresztą w Traktacie dwukrotnie) wskazuje, że terror narzuconej formy dotyczy także słuchaczek niniejszej przemowy. Rozwiewa też wszelkie wątpliwości - używane często przez ojca pojęcie „materii” obejmuje także człowieka.

Jeżeli Traktat o manekinach jest zapowiedzią nowoczesności, to Ulica Krokodyli stanowi jej realizację. Tytułowa ulica (w topografii realnego Drohobycza odpowiadająca Stryjskiej) jest centrum nowej dzielnicy, a właściwie dystryktu przemysłowo-handlowego, „koncesją naszego miasta na rzecz nowoczesności i wielkomiejskiego zepsucia"30. Należy już do świata, w którym człowiek skuszony możliwościami twórczymi i mnogością materii dąży do ciągłego jej przekształcania, a będąc jedynie stworzeniem (a nie Stworzycielem), w rezultacie produkuje tandetę, „twory [...] jak gdyby prowizoryczne, na jeden raz zrobione"31. Ulica stworzona $\mathrm{z}$ pogwałceniem wszystkich zasad planowania przestrzennego staje się parodią samej siebie. Tandetne są więc te sklecone naprędce budynki o karykaturalnych fasadach, oblepione sztukateriami z popękanego gipsu. Groteskowe są nieheblowane portale podmiejskich domków imitujących wielkomiejskie kamienice. W swej bylejakości zdają się bezpośrednio korespondować z proroczymi słowami kupca bławatnego, który zapowiada: „nie będziemy kładli nacisku na trwałość ani solidność wykonania [...] Z tyłu mogą być po prostu zszyte płótnem lub pobielone"32. Właściwość tę zauważa jego syn, który odwiedzając ulicę Krokodyli, stwierdzi: „już na bokach rozwiązuje się i rozprzęga ta zaimprowizowana maskarada i, niezdolna wytrwać w swej roli, rozpada się za nami w gips i pakuły, rupieciarnie jakiegoś ogromnego, pustego teatru"33. Dzielnica ta jawi nam się więc jedynie jako pretekst do odgrywania bezmyślnej inscenizacji nowoczesności, a nie przestrzeń prawdziwego życia. Ale tandetne są nie tylko twory produkowane przez mieszkańców ulicy Krokodyli, oni także, jak pamiętamy, są przecież wybrakowanymi tworami. Z perspektywy obserwującego tworzą w swej masie „szary, bezosobisty tłum”, przypominają „senny korowód marionetek”34. Jako postaci stworzone, zgodnie z postulatem Jakuba, „dla jednego gestu, dla

B. Schulz, Traktat o manekinach. Ciag dalszy, s. 38.

30 Idem, Ulica Krokodyli, s. 80.

31 Idem, Traktat o manekinach albo Wtóra Księga Rodzaju, s. 37.

32 Ibidem.

33 Idem, Ulica Krokodyli, s. 81.

34 Ibidem. 
jednego słowa”, prawowitemu mieszkańcowi miasta, czyli przybyszowi z okolic Rynku, jawią się tylko w swych fragmentach, nigdy jako samodzielne, pełnowartościowe jednostki. „Czasem tylko wyławiamy z tego gwaru wielu głów jakieś ciemne, żywe spojrzenie, jakiś czarny melonik nasunięty głęboko na głowę, jakieś pół twarzy rozdarte uśmiechem, z ustami, które właśnie coś powiedziały, jakąś nogę wysuniętą w kroku i tak już zastygłą na zawsze"35. Ten melonik, ten uśmiech, to pół twarzy, ta noga są być może jedynymi rekwizytami, które posiadają te przypominające manekiny postaci, by zagrać swoją rolę. Ale uważnemu obserwatorowi, jakim jest nasz narrator, nie umknęły wszakże wewnętrzne cechy, które, co zaskakujące, właściwe są bez wyjątku wszystkim mieszkańcom tej dzielnicy. Nowoczesne społeczeństwo ulicy Krokodyli składa się z jednostek bez „gęstości” i bez charakteru. Charakterystyczne jest dla niego zniwelowanie granic i hierarchii, dobrowolne poddanie się degeneracji. Rozluźnienie moralne dotyczy kwestii seksualności. „Każda kobieta w tej dzielnicy jest kokotą”. Żony fryzjerów czy kapelmistrzów kawiarnianych przypominają prostytutki. Seksualizacja dotyczy także dzieci - dziewcząt szkolnych, które w charakterystyczny sposób noszą kokardy i stawiają nogi. Nieostrość granic, niepewność form dotyczy zaś również kwestii płciowości. Napotkany przez narratora subiekt „chwilami robi wrażenie transwestyty”. Warto podkreślić, że wszyscy ci nowocześni ludzie, „ta tandetna odmiana człowieka", nie powstali w wyniku ewolucji rodzimych mieszkańców miasta. Są oni przybyszami, a powodem ich przybycia była pogoń za pieniędzmi, za nowym rynkiem dla ich nowoczesnych, tandetnych wyrobów, za obszarami, które mogliby skolonizować swoim „Confiserie Manucure, King of England”. Podobny obraz ludzi nowej epoki, nowych mieszczan szkicuje w cytowanym już tutaj Zmierzchu Zachodu Oswald Spengler: „zamiast typowego, zrośniętego z ziemią ludu - nowy nomada, pasożyt, mieszkaniec wielkiego miasta, ów wyzbyty tradycji, występujący w bezkształtnej płynnej masie człowiek czystych faktów, irreligijny, inteligentny, niepłodny [...]"36.

Dzielnica, nazwana już wcześniej dystryktem handlowo-przemysłowym, jest opisywana przez narratora w znacznej mierze za pomocą odwołań do sfery ekonomii, a ściśle rzecz biorąc - handlu. Nie jest to zaskakujące - narrator, jako syn kupca bławatnego, jest szczególnie uwrażliwiony na te właśnie obszary działalności mieszkańców ulicy Krokodyli, którzy inaczej podchodzą do spraw sprzedaży niż mieszkańcy centrum, niż Jakub. Ojciec, reprezentant ostatniego pokolenia przemijającego świata, wielką wagę przykładał do handlowego ceremoniału, gdy starzy i pełni godności kupcy „obsługiwali klientów ze spuszczonymi oczyma, w dyskretnym milczeniu, i pełni byli mądrości i wyrozumienia dla ich 
najtajniejszych życzen"' ${ }^{37}$. Jednak dla nowoczesnych kupców z ulicy Krokodyli handel przybiera trzeźwe formy komercjalizmu, jaskrawo rzuca się w oczy użytkowość, która dotyczy tu wszystkiego. Najsilniej uwidacznia się ona w samym pejzażu dzielnicy. Wszechobecne reklamy sprawiają wrażenie, że ogląda się nie prawdziwe miasto, lecz czarno-biały, ilustrowany prospekt ${ }^{38}$. Podobieństwo jest tak uderzające, że narrator posuwa się do niezwykłego na tle całego tekstu zabiegu. Podczas gdy w opisach Schulza często dochodzi do zatarcia granic pomiędzy metaforą a metamorfozą, tutaj podkreślona została „realna” wartość zastosowanego porównania. Czytamy: „Podobieństwo to wychodziło poza zwykłą metaforę, gdyż chwilami, wędrując po tej części miasta, miało się w istocie wrażenie, że wertuje się w jakimś prospekcie, w nudnych rubrykach komercyjnych ogłoszeń, wśród których zagnieździły się pasożytniczo podejrzane anonse, drażliwe notatki, wątpliwe ilustracje"39. Tutaj jeszcze rubryki ogłoszeń wydają się narratorowi nudne, czarno-białe ilustrowane prospekty sprawiają przygnębiające wrażenie. Ale, jak wiemy, już wkrótce właśnie w katalogu reklamowym doszuka się prawdziwego Autentyku, poszukiwanej przez siebie Księgi. To pokrewieństwo między wyklejonym reklamami krajobrazem ulicy Krokodyli a wnętrzem Księgi (które wręcz „wychodzi poza zwykłą metaforę”) każe zastanowić się nad wynikającymi z niego konsekwencjami dla interpretacji całego analizowanego opowiadania. Skoro Biblia, przywołująca tutaj na myśl skojarzenia z religią, z tradycją, $\mathrm{z}$ hierarchią, a więc raczej, posługując się po raz kolejny przywoływaną niejednokrotnie dychotomią, kojarzącą się z centrum, z Rynkiem, koniec końców zostaje jednak odrzucona i nazwana skażonym apokryfem, czy oznacza to, że również dawny świat należałoby uznać za falsyfikat? Co oznacza w takim razie wybór książki reklamowej? Czy nazwanie jej Autentykiem wiąże się również z rozpoznaniem esencji życia w fałszu świata ulicy Krokodyli? Koncentrując się jednak na bardziej dosłownej warstwie tego opisu, spróbujmy wyobrazić sobie tę ulicę. Mamy do czynienia z typowym, zdawałoby się, wielkomiejskim krajobrazem, pełnym „konglomeratów szyldów, ślepych okien biurowych, szklistoszarych wystaw, reklam i numerów”, pod którymi „płynie rzeka tłumu”. Ulica Krokodyli zdaje się wręcz wielkomiejską arterią, bulwarem. Jednak wkrótce okazuje się, że także sama ulica, podobnie jak jej mieszkańcy, jest tylko tandetą, nieudolną, cienką jak papier imitacją. Szyldy zrobione są z kartonu, a główny trakt pokrywa ubita glina. To właśnie pozór, udawana wielkomiejskość zostały poddane przez narratora największej krytyce. Nie sama istota wielkomiejskości, tylko jej imitacja, prowincjonalny wytwór pretendujący do roli czegoś więcej.

37 B. Schulz, Sklepy cynamonowe, w: idem, Opowiadania. Wybór esejów i listów, s. 61.

38 Por. A. Nowaczewski, op. cit., s. 201.

39 B. Schulz, Ulica Krokodyli, s. 73. 
Kolejnym ważnym tekstem Schulza, który podejmuje w znacznej mierze tematykę społeczną, jest Wiosna ze zbioru Sanatorium pod Klepsydra. O jego niezwykłości świadczy chociażby, wyjątkowe na tle poetyki innych tekstów Schulza, przywołanie postaci historycznej - cesarza Franciszka Józefa I. Pozwala to na, bardziej uprawnione niż gdzie indziej, poszukiwanie odniesień do konkretnej sytuacji dziejowej. Epoka ta obejmowałaby lata panowania władcy - od 1848 do 1916 roku, czasy, jak się zdaje, wcześniejsze wobec wydarzeń związanych z ulicą Krokodyli. Choć Franciszek Józef nie staje się jednym z pełnoprawnych bohaterów Wiosny, tekst często nawiązuje do jego osoby. Umityczniony cesarz jest niewidzialnym kreatorem rzeczywistości, sprawcą wydarzeń, z których skutkami musi mierzyć się narrator. Jest kimś, do kogo nieustannie się odwołuje, żeby wytłumaczyć zastaną sytuację zarówno na poziomie mikro (domyślamy się, że mógł mieć swój udział w historii Bianki), jak i makro (Franciszek Józef zdaje się przenikać każdą sferę życia swoich poddanych). Tutaj będzie nas interesować zwłaszcza ten drugi, ponadindywidualny poziom. Jak więc wygląda świat pod panowaniem cesarza? Przede wszystkim jest to świat przełomu, pogrążony w rozpadzie, ostatkiem sił utrzymywany przez tego wielkiego epigona w swoim dawnym kształcie. Był już taki w chwili obejmowania przez niego tronu, "gdy pojawił się na widowni świata w generalskim zielonym pióropuszu, w turkusowym płaszczu do ziemi, lekko zgarbiony i salutujący, świat doszedł był w swoim rozwoju do jakiejś szczęśliwej granicy. Formy wszystkie, wyczerpawszy swą treść w nieskończonych metamorfozach, wisiały już luźno na rzeczach, na wpół złuszczone, gotowe do strącenia. Świat przepoczwarzał się gwałtownie, wylęgał w młodych, szczebiotliwych i niesłychanych kolorach, rozwiązywał się szczęśliwie we wszystkich węzłach i przegubach"40. To przekonanie o ograniczonych możliwościach rozwoju ludzkości zdaje się korespondować z diagnozami cytowanego już, niezwykle zresztą popularnego za życia Schulza, Spenglera, który twierdził: „Czysta cywilizacja jako proces historyczny polega na stopniowym eksploatowaniu nieorganicznych, obumarłych już form"41. W jaki sposób udaje się więc Franciszkowi Józefowi powstrzymać chwilowo nadciągający rozpad? Poprzez wyrugowanie ze świata poezji, zastąpienie jej pozbawionym złudzeń i romantyki „państwem prozy”, ograniczenie możliwości twórczych i stworzenie nieprzekraczalnych granic, „w których już raz na zawsze świat jest zamknięty”42. Jest to państwo represyjne, w którym obowiązuje zasada jednolitości, a jego głównym celem jest tkwienie w tym stanie, utrzymywanie iluzji niezmienności. Ten wielki projekt Franciszka Józefa z pewnością nie udałby się, gdyby nie wsparcie $\mathrm{w}$ postaci rozbudowanego aparatu biurokratycznego. Składa się on z podatnych

40 Ibidem.

41 O. Spengler, op. cit., s. 44.

42 B. Schulz, Wiosna, s. 155. 
na urok autorytetu jednostek, których lojalna natura predysponowała do pełnienia służby. Dla kogo jednak ten „starzec oschły i stępiały”43 mógł być pociągający? Przede wszystkim dla tych, którzy nadchodzącymi zmianami byli przerażeni, którzy postanowili kurczowo trzymać się ułudy statycznego świata wykreowanej przez cesarza. Byli to mianowicie „lojalni i przewidujący ojcowie rodzin”44.

Świat ludzki jest dla p. Schulza bliższy, niż z początku może się wydawać. Choć rzadko na kartach swoich opowiadań dotyka społecznych tematów wprost, gdy (za radą samego pisarza) czyta się jego teksty niejako pomiędzy wierszami i, pamiętając, że „wszystkie rzeczy są ze sobą powiązane”, łączy z pozoru odległe ich elementy, okazuje się, że to właśnie zainteresowanie człowiekiem i jego relacjami z otoczeniem stanowi ważną część jego twórczości. O związkach Brunona Schulza z nurtem prozy zaangażowanej społecznie świadczyć może jego przynależność do grupy literackiej „Przedmieście”. Wiele z postulatów zawartych w przedmowie do pierwszego wydania pracy zbiorowej Zespołu zdaje się pokrywać z założeniami pisarskimi Schulza. Wspólne jest tutaj dystansowanie się od oficjalnego nurtu kultury, odwoływanie się do tradycji awangardowych, czerpanie inspiracji z rzeczywistości czy poczucie zbliżającego się schyłku epoki. Właśnie te przeczucia kresu dotychczasowego świata wywarły, zdaje się, najsilniejsze piętno na całej twórczość pisarza. Nie tylko bowiem zaowocowały maniakalnym wręcz porządkowaniem tegoż świata, wpisywaniem wszystkiego w sens uniwersalny, lecz także wyrażane są bezpośrednio w tekście, wielokrotnie powracają w poszczególnych opowiadaniach. Spośród nich wyróżniają się dwa: Ulica Krokodyli (nieodłącznie związana z Traktatem o manekinach) oraz Wiosna. Pierwsze dotyczące już świata nowoczesności, drugie - jeszcze ery Franciszka Józefa. Razem tworzą interesujący obraz przemiany, która tak bardzo fascynowała pisarza. Od tradycjonalistów, pełnych wzniosłych idei i pokornie adorujących dzieła boskie, aż po „kreatury bez gęstości”, manekiny, wytwór demiurgicznych pasji. Od hierarchicznie ukształtowanego, uwiecznionego na barokowym prospekcie miasta, po nową dzielnicę przedmiejską, roszczącą sobie prawo do stanowienia nowego centrum. Lecz nie sposób traktować opisanej zmiany społecznej jedynie w kontekście przełomu XIX i XX wieku. Choć bez wątpienia pierwotnie związana jest z tym szczególnym okresem, jednocześnie zyskuje wymiar uniwersalny - odwołuje się przecież do cyklicznie powracającego poczucia kryzysu. Udało się zatem Schulzowi w pełni zrealizować swój pisarski program - wpisał swoje dzieło w ponadjednostkowy sens. 